\title{
Amputation of Penis Due To Electrocution- A Case Report
}

\author{
Vedant Kulshrestha ${ }^{1}$, Mohammad Amjad ${ }^{2}$ \\ ${ }^{1}$ Senior Resident, ${ }^{2}$ Junior Resident, Department of Forensic Medicine \& Toxicology, Vardhman Mahavir Medical \\ College \& Safdarjung Hospital, New Delhi
}

\begin{abstract}
Electricity is an integral part of modern society. Without electricity the existence of human life seems difficult, but it has the capacity to stand life and destroyed the life up to the death. The most fatalities caused due to electricity are accidental and result from passage of an electric current [both low \& high voltage] through the body. Penile trauma presents a difficult physical and psychological problem and is rare. The causes of penile trauma are varied; it can be iatrogenic or caused by traffic accidents, thermal and electric burns, ritual circumcision, animal bites, gunshots or self-mutilation. The type and extent of penile trauma varies from mild to severe injuries, sometimes even with total amputation.

In the present case, a 24 year old young male from Palwal (Haryana) sustained electric burn injuries while he was standing in the balcony and came in contact with high voltage electric wires passing in front of the balcony. He was admitted in Safdarjung hospital, Delhi and expired on the same day. During autopsy electric contact burn marks were present on unusual sites of the body like head, neck, abdomen, pubic region and root of penis with amputation of penis. Electric flash burns were also present on different parts of the body along with fracture of cervical vertebra.
\end{abstract}

Key Words: Electricity, Electric current, Electric burn injuries, Electrocution, Penile trauma, Amputation of penis.

\section{Introduction}

Electricity is an integral part of modern society. Without electricity the existence of human life seems difficult, but it has the capacity to stand life and destroyed the life up to the death. The most fatalities caused due to electricity are accidental and result from passage of an electric current [both low \& high voltage] through the body. Suicides and homicides from electrocution are very rare. ${ }^{1}$ In comparison to western countries India shows relatively higher incidence of electrocution. ${ }^{2}$ Penile trauma presents a difficult physical and psychological problem and is rare, because

\section{Corresponding Author:}

\section{Dr. Vedant Kulshrestha}

Senior Resident, Department of Forensic Medicine \& Toxicology, Vardhman Mahavir Medical College \& Safdarjung Hospital, New Delhi.

E-mail: vedantkkulshrestha@yahoo.co.in

Mob. No.- 8105979445 the penis is a mobile organ enveloped into loose skin, well protected by its position; however, the penis is more prone to trauma during sexual intercourse while rigidly erect. ${ }^{3}$ The causes of penile trauma are varied; it can be iatrogenic or caused by traffic accidents, thermal and electric burns, ritual circumcision, animal bites, gunshots or self-mutilation. ${ }^{4,5,6,7}$ Reports of trauma to the external genitalia are sporadic. The type and extent of penile trauma varies from mild to severe injuries, sometimes even with total amputation. ${ }^{8}$

\section{Case history:}

A 24 year old young male from Palwal (Haryana) sustained electric burn injuries on 11/11/2018 at around 5:30 AM while he was standing in the balcony and came in contact with high voltage electric wires passing in front of the balcony. He was initially taken to a private hospital at Palwal. Then referred and admitted at Safdarjung Hospital, Delhi on 11/11/2018 at 09:10 $\mathrm{AM}$ where he died while undergoing treatment on 12/11/2018 at 12:00 AM. 


\section{Autopsy findings:}

Dead body was of a male wrapped in white coloured hospital sheet. Moderately built, Cornea was hazy. Rigor mortis was present all over the body. Post mortem staining was present over back except pressure and burnt areas, and was fixed.

\section{Antemortem external injuries:}

(1) Electric contact burn marks, 2 in number, of sizes $5 \mathrm{~cm} \times 3.5 \mathrm{~cm} \times$ scalp tissue deep and $3 \mathrm{~cm} \times 2 \mathrm{~cm}$ $\mathrm{x}$ scalp tissue deep respectively were present over back of head on left side. Margins were irregular, everted and base was indurated. Surrounding area was pale. Blackening was present around the wound. Scalp hair were singed at places. (Fig. 1)

(2) Electric contact burn mark of size $12 \mathrm{~cm} \mathrm{x}$ $5 \mathrm{~cm} \times$ muscle deep was present over nape of neck. Margins were irregular, everted and base was indurated. Surrounding area was pale. Blackening was present around the wound. (Fig. 1)

(3) Electric contact burn mark of size $7 \mathrm{~cm} \mathrm{x} 3 \mathrm{~cm} \mathrm{x}$ subcutaneous tissue deep was present horizontally over right side front of abdomen, situated $10 \mathrm{~cm}$ below the umbilicus. Margins were irregular, everted and base was indurated. Surrounding area was pale. Blackening was present over and around the wound. (Fig. 2)

(4) Electric contact burn mark of size $12 \mathrm{~cm} \times 3.5$ $\mathrm{cm} \times$ muscle deep was present horizontally over pubic region on right side. Margins were irregular, everted and base was indurated. Surrounding area was pale. Blackening and charring was present over and around the wound. (Fig. 2)

(5) Electric contact burn wound of size $5 \mathrm{~cm} \mathrm{x}$ $4.5 \mathrm{~cm} \times$ muscle deep was present over root of penis and penis was amputated and missing. Margins were irregular and everted, and base of wound was indurated. Blackening and charring was present over and around the wound. (Fig. 2)

(6) Epidermal to dermo-epidermal electric flash burn injuries were present in patches over face and neck, in patches over back of chest, in patches over front of abdomen, external genitalia and in patches over left forearm. Right upper limb including both palms, front of chest, back of abdomen and both lower limbs including soles were spared. Total electric flash burn injury involved about $20 \%$ of total body surface area. Burnt area showed redness, peeling and blackening of skin at places. (Fig. 1, 2, 3)

Internal examination: Cervical vertebra was fractured at $\mathrm{C} 3-\mathrm{C} 4$ vertebral level with blood extravasation at fractured site. Underneath spinal cord was contused. Lungs were congested and edematous. Stomach was empty with no unusual smell and normal mucosa. All other organs were congested.

Opinion regarding cause of death was given as shock as a result of electrocution.

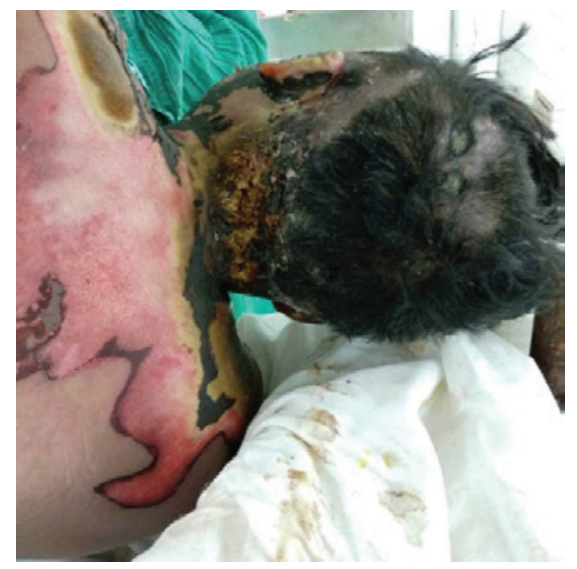

Fig. 1- Figure showing electric contact burn marks over back of head and nape of neck, and electric flash burn injuries

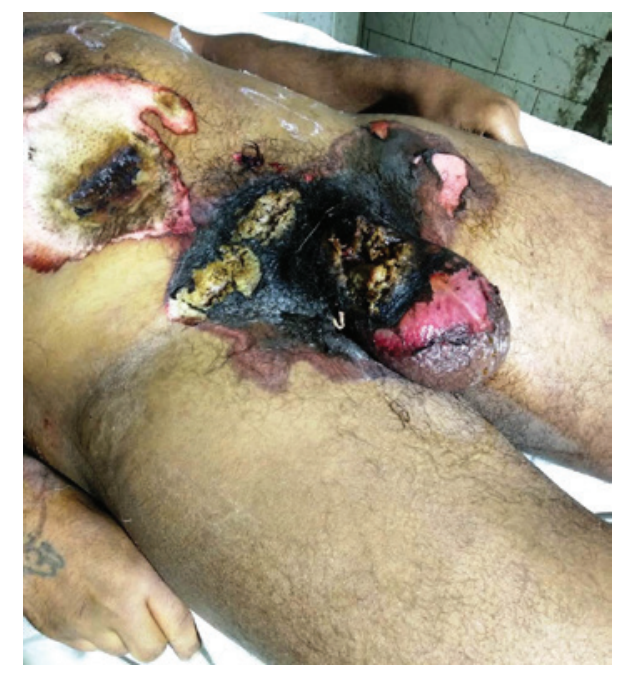

Fig. 2- Figure showing electric contact burn marks over front of abdomen, pubic region and penis with amputation of penis due to electrocution, and electric flash burn injuries 

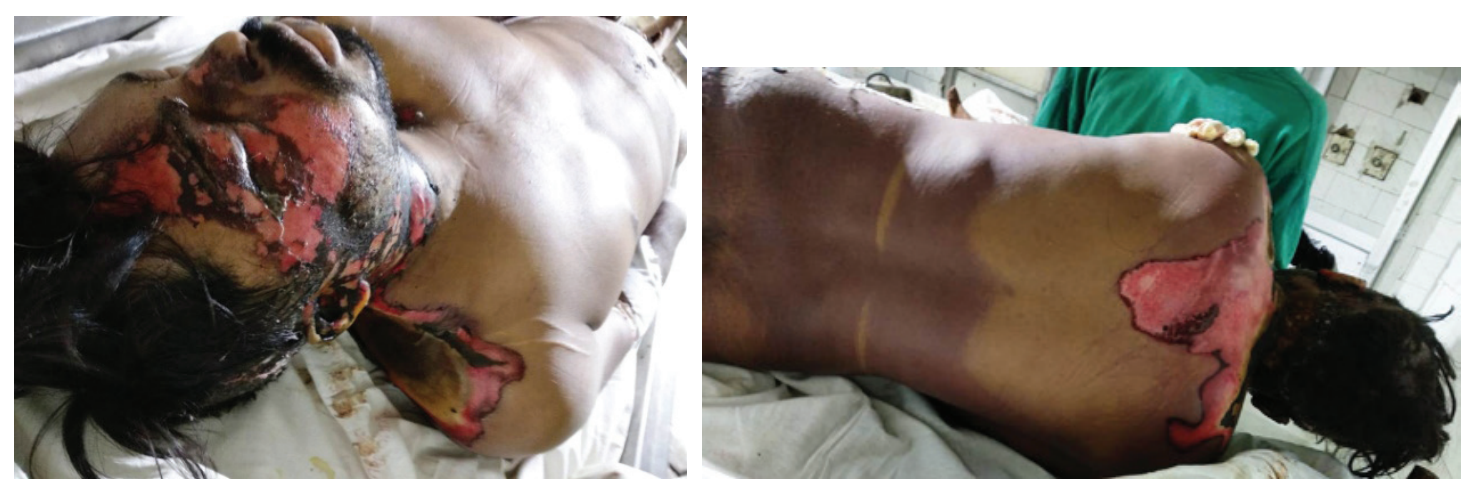

Fig. 3- Figure showing electric flash burn injuries over face, neck, shoulder and upper part of back of chest

\section{Discussion}

In a study done by the auther in Bangalore, majority $48.8 \%$ of electrocution cases were young adults in the age group of 21-30 years followed by 31-40 years which include $17.1 \%$ cases. Majority of victims of fatal electrocution were male $(85.4 \%)$ and only $14.6 \%$ were female. ${ }^{9}$ The studies conducted by Guntheti BK et al ${ }^{1}$, Rajesh B et $\mathrm{al}^{10}$ and Shaha KK et $\mathrm{al}^{11}$ also reported that most of the victims were from 21-30 years age group. Similar findings of male dominance were also reported by them.

In the present case also the victim of electrocution was a 24 year old young male.

The reason for such a marked male predominance of young age in a variety of studies from different communities is probably the fact that mostly males of young age are involved in the electrical works.

Accidental electrocution among these would have occurred because of carelessness, ignorance, haste, malfunction of appliances or equipment such as ineffective insulation, lack of protective earthing, faulty grounding and short circuits. ${ }^{12}$

In a study conducted by Ragui $\mathrm{S}$ et $\mathrm{al}^{13}$ in Manipur, most of the victims were electrocuted on the road side (68\%) and the remaining victims were electrocuted in their houses. While in a study conducted by Pathak AK et $\mathrm{al}^{14}$ at Jaipur $70 \%$ victims were electrocuted at home.

In the present case the victim got electrocuted at home while he was standing in balcony.
In the study done by the auther in Bangalore, in most of the cases $(46.3 \%)$, there were only entry wounds. While in $29.3 \%$ cases both entry and exit wounds were seen. Electrical flash burns were seen in $36.6 \%$ cases. Majority of cases (75.6\%) showed electric contact marks present on upper limbs including palms and fingers. ${ }^{9}$ This usual site of electric entry mark is also mentioned in many textbooks. ${ }^{15,16}$ In a study conducted by Rajesh $\mathrm{B}$ et $\mathrm{al}^{10}, 44.5 \%$ cases showed only entry wounds while in $27.8 \%$ both entry and exit wounds were present. In the study conducted by Guntheti BK et al ${ }^{1}, 40.3 \%$ cases showed only entry wounds, $35.48 \%$ cases showed both entry and exit wounds. While $25.8 \%$ cases showed flash burns.

In the present case both electric contact burn marks and electric flash burns were seen. Electric contact burn marks were present on unusual sites of the body like head, neck, abdomen, pubic region and root of penis with amputation of penis. Fracture of cervical vertebra also present.

\section{Conclusion}

The etiology of penile trauma varies but ranges from self-infliction in psychiatric patients, to industrial accidents or assaults, and rarely from circumcision mishaps. The traumatic amputation of the penis in adults following electrocution is rare. Whenever it happens, it can be devastating to the patient, his spouse and his relatives.

The risk of getting electrocuted from the haphazardly installed electric wires without proper maintenance and careless use of electrical appliances is the matter of concern. Nevertheless, spread of awareness and adoption 
of safety measures are important factors required for prevention of fatal electrocution and penile trauma.

Acknowledgement: All teaching staffs, senior residents and junior residents of Department of Forensic Medicine \& Toxicology, Vardhman Mahavir Medical College \& Safdarjung Hospital, New Delhi.

\section{Conflict of Interest- None.}

Financial Assistance: None.

Ethical Clearance- Not applicable.

\section{References}

(1) Guntheti BK, Khaja S, Singh UP. Pattern of injuries due to electric current. J Indian Acad Forensic Med 2012 Jan- March;34(1):44-48.

(2) Rautji R, Rudra A, Behra C, Dogra TD. Electrocution in South Delhi: a retrospective study. Med Sci Law 2002;(43):350-2.

(3) El-Bahansawy MS, Gomha MA: Penile fractures. The successful outcome of immediate surgical intervention. Int J Imp Res 2000; 12; 273-277.

(4) Amukele S, Lee G, Stock J, Hanna M. 20-year experience with iatrogenic penile injury. $J$ Urol 2003, 170; 1691-1694. [PubMed]

(5) El-Bahnasawy MS, El-Sherbiny MT. Pediatric penile trauma. BJU Int 2002; 90; 92-96.

(6) Gearhart JP, Rock J. Total ablation of the penis after circumcision with electrocautery: a method of management and long-term follow up. $J$ Urol $1989 ; 142 ; 799-801$.

(7) Gomez RG, Castanheira AC, McAninch JW. Gunshot wounds to the male genitalia. $J$ Urol
1993; 150; 1147-1149.

(8) Perovic SV. Severe penile injuries: etiology, management and outcomes. Urol Pol 2005;58(3).

(9) Kulshrestha V, Prabha S, Havanur BL. Pattern of electrical injuries in IT city Bangalore- an autopsy based retrospective study. J Medico-Legal Update 2016 July-Dec;16(2):228-231.

(10) Rajesh B, Gambhir SO, Khan TM. Patterns of electrical injuries: a prospective study in autopsy cases. J SIMLA 2014 Mar;6(1):5-8.

(11) Shaha KK, Joe AE. Electrocution related mortality: a retrospective review of 118 deaths in Coimbatore, India, between January 2002 and December 2006. Med Sci Law 2010 Apr;50(2):724.

(12) Mellen PF, Weedn VW, Kao G. Electrocution: a review of 155 cases with emphasis on human factors. J For Sci 1992;37:1016-22.5.

(13) Ragui S, Meera T, Singh PK, Devi PM, Devi AS. A study of electrocution deaths in Manipur. J Med Soc 2013;27(2):124-126.

(14) Pathak AK, Disania NL. Pattern and seasonal variations in death due to electrocution: a retrospective study. Int J Med Sci Public Health 2015;4(1):19-22.

(15) Kumar A. Textbook of Forensic Medicine (Medical Jurisprudence and Toxicology). $3^{\text {rd }}$ ed. New Delhi: Avichal Publishing Company; 2011. p. 161.

(16) Mathiharan K, Patnaik AK. Modi's medical jurisprudence and toxicology. $23^{\text {rd }}$ ed. New Delhi, India: Butterworths; 2005. p. 645-655. 